\title{
AKTIVITAS ANTIBAKTERI EKSTRAK AIR KULIT BAWANG MERAH (Allium cepa L.) TERHADAP BAKTERI Propionibacterium acnes
}

\author{
Hayatus Sa`adah ${ }^{1}, \mathrm{Supomo}^{2}, \mathrm{Musaenah}^{3}$ \\ ${ }^{1,2,3}$ Stikes Samarinda
}

Email korespondensi: hayatus.akfarsam@gmail.com

\begin{abstract}
ABSTRAK
Bakteri Propionibacterium acnes merupakan salah satu penyebab jerawat. Kulit bawang merah mengandung mengandung senyawa flavonoid, tanin dan saponin yang berpotensi memiliki aktivitas antibakteri. Tujuan dari penelitian ini adalah untuk mengetahui apakah ekstrak air kulit bawang merah mempunyai aktivitas antibakteri terhadap Propionibacterium acnes serta mengetahui konsentrasi yang dapat menghambat pertumbuhan bakteri Propionibacterium acnes. Penelitian ini merupakan penelitian eksperimental. Tahapan penelitian dimulai dengan ekstraksi kulit bawang merah menggunakan metode infundasi. Aktivitas antibakteri diuji menggunakan metode difusi sumuran. Sampel bakteri yang digunakan adalah bakteri Propionibacterium acnes, dengan konsentrasi ekstrak 5\%, 10\%, 20\% dan 40\%. Kontrol positif yang digunakan yaitu klindamisin $150 \mathrm{mg}$ dan kontrol negatif yang digunakan dimetil sulfoksida 1\% (v/v). Data dianalisi dengan uji statistik metode Kolmogorov-Smirnov. Hasil pengukuran zona hambat ekstrak air kulit bawang merah dengan konsentrasi 5\%, 10\%, 20\% dan 40\% terhadap bakteri Propionibacterium acnes secara berurutan sebesar $12,8 \mathrm{~mm}, 13 \mathrm{~mm}, 14,33 \mathrm{~mm}$ dan $15,50 \mathrm{~mm}$ dengan kategori kuat. Data hasil pengukuran zona hambat pertumbuhan bakteri dianalisis secara statistik dengan metode Kruskal-Wallis didapat hasil 0,053 yang menunjukkan bahwa uji tersebut memiliki signifikan $(\mathrm{P}>0,05)$ dengan keputusan yang berarti tidak terdapat perbedaan bermakna antara semua konsentrasi.
\end{abstract}

Kata kunci: Aktivitas Antibakteri, Propionibacterium acnes, kulit bawang merah (Allium cepa L.) 


\title{
ANTIBACTERIAL ACTIVITY OF SHALLOT PEELS (Allium cepa L.) WATER EXTRACT ON BACTERIA Propionibacterium acnes
}

\begin{abstract}
Propionibacterium acnes is one of the causes of acne. Shallot peels contains flavonoids, tannins and saponins which potentially have antibacterial activity. The purpose of this study was to determine whether the water extracts of shallot peels has antibacterial activity against Propionibacterium acnes and determine the concentration which can inhibit the growth of bacteria Propionibacterium acnes. This research is an experimental study. Research stage begins with the extraction of shallot peels using infundation. Antibacterial activity was tested using the diffusion method with Cup-plate technique. Propionibacterium acnes used as sample of bacteria, with extract concentrations of 5\%, 10\%, 20\% and 40\%. Positive controls used are clindamycin $150 \mathrm{mg}$ and negative controls were used dimethyl sulfoxide $1 \%(v / v)$. Data was analyzed with statistical test of Kolmogorov-Smirnov method. The measurement results inhibition zone of shallot peels water extract with a concentration of 5\%, 10\%, 20\% and 40\% of the bacteria Propionibacterium acnes sequentially by $12.8 \mathrm{~mm}, 13 \mathrm{~mm}, 14.33 \mathrm{~mm}$ and $15.50 \mathrm{~mm}$ in the strong category. The measurements of bacterial growth inhibition zone was statistically analyzed with the Kruskal-Wallis method gained 0,053 results indicating that the test has a significant effect $(P>0.05)$ with a decision means that there is no significant difference between all concentrations.
\end{abstract}

Keywords: Antibacterial activity, Propionibacterium acnes, Shallot peels

\section{PENDAHULUAN}

Jerawat merupakan penyakit kulit yang dikenal dengan acne vulgari. Banyak faktor yang dapat menyebabkan munculnya jerawat salah satunya adalah bakteri Propionibacterium acnes. Penyebaran bakteri Propionibacterium acnes dan peradangan klonik folikel sebasea dengan gambaran klinis berupa komedo, papul, pustula, nodus, kista pada tempat predileksinya (muka, bahu, leher, dada, punggung bagian atas dan lengan bagian atas) (Jawetz dkk., 2001).

Salah satu bahan alam yang berpotensi sebagai obat jerawat adalah bawang merah (Allium cepa L.). Secara empiris, bawang merah digunakan untuk mengatasi berbagai gangguan kesehatan, termasuk sakit tenggorokan, penyakit kulit (seperti panu, kudis, eksim dan jerawat), keropos tulang, diabetes, kolesterol, antioksidan dan antimikroba (Wibowo, 2007). Bawang merah juga mengandung protein, mineral, 
sulfur, antosianin, kaemferol, karbohidrat dan serat. Bawang merah juga memiliki efek antiinflamasi dan antibakteri (Soebagio dkk., 2007).

Kulit bawang merah merupakan bagian dari umbi bawang merah yang tidak termanfaatkan dan berdasarkan dari hasil penelitian Manullang (2010) hasil uji skrining fitokimia menyatakan bahwa serbuk kulit bawang merah mengandung senyawa flavonoid, tanin, saponin, glikosida dan steroid/triterpenoid. Pada kulit bawang merah juga terdapat Senyawa metabolit sekunder yaitu senyawa kuersetin dan rutin (Machavarapu dkk., 2013). Senyawa tersebut sebagian terdapat pada bagian kulit bawang merah (Naidu dkk., 2012).

Penelitian Arif pada tahun 2013, tentang uji aktivitas antibakteri ekstrak terpurifikasi kulit bawang merah (Allium cepa L.) terhadap bakteri Staphylococus aureus, pada konsentrasi $20 \%$ dapat memberikan daya hambat sebesar 5,30 $\mathrm{mm}$. Oleh sebab itu perlu dilakukan penelitian untuk mengetahui aktivitas antibakteri ekstrak air kulit bawang merah terhadap Propionibacterium acnes.

\section{METODE PENELITIAN MATERIAL}

Media Nutrient Broth, agar, glukosa, bakteri Propionibacterium acnes, ekstrak air kulit bawang merah, $\mathrm{FeCl}_{3} 1 \%$, asam klorida $2 \mathrm{~N}$, pereaksi mayer, pereaksi bouchardat, pereaksi dragendorf, serbuk $\mathrm{Mg}, \mathrm{HCl}$ pekat, amil alkohol, etanol 70\%, klindamisin $150 \mathrm{mg}$, DMSO (dimetil sulfoksida) $1 \% \mathrm{v} / \mathrm{v}$. Bahan kimia yang digunakan kecuali dinyatakan lain adalah berkualitas pro analisis (E. Merk, p.a.).

\section{Rancangan Penelitian \\ Pembuatan Ekstrak Air Kulit Bawang Merah}

Lima puluh gram kulit bawang merah dimasukkan ke dalam panci infus ditambahkan 1 liter air suling dan dididihkan kulit bawang merah selama 15 menit. Kulit bawang merah diserkai selagi panas menggunakan kain flanel yang ditampung di dalam beaker glass, filtrat yang diperoleh kemudian dipekatkan di atas penangas hingga menjadi ekstrak kental.

\section{Skrining Fitokimia}

Dilakukan skrining fitokimia untuk mengetahui kandungan metabolit sekunder dalam ekstrak air kulit bawang merah. Skrining fitokimia yang dilakukan meliputi pemeriksaan uji alkaloid, flavonoid, tannin dan saponin.

\section{Uji Aktifitas Antibakteri Ekstrak} Air Kulit Bawang Merah Pembuatan media agar miring

Nutrient Broth ditimbang sebanyak 0,28 gram, 0,7 gram agar dan 0,35 gram glukosa, kemudian dilarutkan dalam 35 $\mathrm{mL}$ aquadest menggunakan beaker glass. Setelah itu dipanaskan di atas hotplate sambil diaduk sampai mendidih. Sebanyak $15 \mathrm{~mL}$ dituangkan masing-masing pada tabung reaksi steril dan ditutup dengan kapas. Media tersebut disterilkan dalam autoklaf pada suhu $121^{\circ} \mathrm{C}$ selama 15 menit, kemudian dibiarkan pada suhu ruangan selama 20 
menit sampai media memadat pada kemiringan $30^{\circ}$. Media agar miring digunakan untuk inokulasi bakteri.

\section{Kultur bakteri pada media}

Bakteri uji diambil dengan jarum ose steril, lalu ditanamkan pada media agar miring dengan cara menggores. Selanjutnya diinkubasi dalam inkubator pada suhu $37^{\circ} \mathrm{C}$ selama 24 jam.

\section{Pembuatan media Nutrient Agar (NA)}

Ditimbang sebanyak 0,72 gram Nutrient Broth, 1,8 gram agar dan 0,9 gram glukosa, kemudian dilarutkan dengan $90 \mathrm{~mL}$ aquadest dalam beaker glass. Setelah itu dipanaskan di atas hotplate sambil diaduk sampai mendidih lalu disterilkan di dalam autoklaf pada suhu $121^{\circ} \mathrm{C}$ selama 15 menit. Dituang media NA dalam keadaan panas sebanyak $20 \mathrm{~mL}$ ke dalam cawan petri dengan tiga kali pengulangan. Media didiamkan sampai mengeras.

\section{Pembuatan Suspensi Bakteri}

\section{Propionibacterium acnes}

Koloni bakteri uji yang telah diremajakan diambil dengan jarum ose lalu dimasukkan ke dalam beaker glass yang telah diisi dengan aquadest steril. Pengenceran dibuat dan diukur kekeruhan dari suspensi dengan spektrofotometer UV-Visibel sampai diperoleh suspensi bakteri dengan nilai transmitan $70-75 \%$ pada panjang gelombang $600 \mathrm{~nm}$. Diambil suspensi bakteri Propionibacterium acne sebanyak $100 \mu \mathrm{L}$ menggunakan mikropipet dan diletakkan diatas media
NA pada cawan petri kemudian diswab menggunakan lidi kapas, biarkan selama 5-15 menit supaya suspensi bakteri meresap ke dalam agar.

\section{Uji aktivitas antibakteri dengan metode difusi (sumuran)}

Dibuat lubang pada media sebanyak 6 lubang untuk sampel yang akan diuji pada masing-masing cawan petri yaitu kontrol negatif, P1, PII, PIII,PIV dan 1 lubang pada cawan petri untuk kontrol positif. Lubang kontrol positif diisi dengan klindamisin $1 \%$, kontrol negatif diisi dengan DMSO $1 \%$ (v/v), PI diisi dengan ekstrak air kulit bawang merah 5\%, PII diisi dengan ekstrak air kulit bawang merah $10 \%$, PIII diisi dengan ekstrak air kulit bawang merah $20 \%$ dan PIV diisi dengan ekstrak air kulit bawang merah 40\%. Sampel uji didiamkan sampai meresap pada media, kemudian diinkubasi pada suhu $37^{\circ} \mathrm{C}$ selama 24 jam, lalu diukur diameter daya hambat (mm) menggunakan jangka sorong dari masing-masing sampel.

\section{Analisis Data}

Data hasil penelitian yang diperoleh dianalisis menggunakan metode One Way Anova (jika data yang diperoleh berdistribusi normal) atau uji Kruskal-Wallis (jika data tidak berdistribusi normal). Sebelum diuji dengan menggunakan metode One Way Anova, terlebih dahulu dilakukan uji Shapiro Wilk (Uji Normalitas) untuk menentukan apakah data berdistribusi normal atau tidak. 
HASIL DAN PEMBAHASAN

\section{Skrining Fitokimia Kulit Bawang Merah (Allium cepa L.)}

Skrining fitokimia dilakukan untuk mengetahui adanya kandungan senyawa metabolit sekunder yang terkandung dalam ekstrak air kulit bawang merah (Allium cepa L.). Metabolit sekunder adalah senyawa metabolit yang tidak esensial bagi pertumbuhan organisme dan ditemukan dalam bentuk yang berbeda- beda dan unik antara spesies satu dan lainnya. Golongan metabolit sekunder yang akan diperiksa adalah alkaloid, flavonoid, tanin dan saponin. Hasil pengujian skrining fitokimia terhadap ekstrak air kulit bawang merah dapat dilihat pada Tabel 1 berikut:

Tabel 1. Hasil Skrining Fitokimia Kulit Bawang Merah (Allium cepa L.)

\begin{tabular}{|c|c|c|c|c|}
\hline $\mathbf{N}$ & Uji Fitokimia & Pereaksi & & Keterangan \\
\hline \multirow[t]{2}{*}{1} & Alkaloid & Mayer & Endapan putih/kuning & - $($ Kokate, 2001) \\
\hline & & Boucharda & Larutan coklat-hitam & \\
\hline 2 & Flavonoid & $\mathrm{HCl}$ pekat & Terbentuk & $+($ Kokate, 2001$)$ \\
\hline & & & lapisan amil & \\
\hline 3 & Tanin & $\mathrm{FeCl}_{3} 1 \%$ & $\begin{array}{r}\text { Larutan hijau } \\
\text { kehitaman }\end{array}$ & $+($ Kokate, 2001$)$ \\
\hline 4 & Saponin & $\mathrm{HCl} 2 \mathrm{~N}$ & Terbentuk busa & $+($ Harborne, 1987) \\
\hline
\end{tabular}

Hasil skrining fitokimia tersebut menunjukkan bahwa ekstrak air kulit bawang merah mengandung senyawa metabolit sekunder yang terdiri dari flavonoid, tanin dan saponin.

\section{Uji Aktivitas Antibakteri Ekstrak} Air Kulit Bawang Merah

Uji ini dilakukan untuk mengetahui pengaruh ekstrak air kulit bawang merah terhadap pertumbuhan bakteri Propionibacterium acnes yang merupakan agen utama etiologi inflamasi jerawat (Sugita dkk., 2010) dan bersifat anaerob fakultatif. Metode yang digunakan dalam pegujian ini adalah metode difusi sumuran (cupplate technique) karena metode ini sangat cocok untuk pertumbuhan bakteri anaerob fakultatif. Bakteri anaerob fakultatif adalah bakteri yang dapat hidup dengan baik dengan oksigen atau tanpa oksigen. Hasil dalam penelitian ini sesuai dengan penelitian yang telah dilakukan Saputro (2006), yang menyatakan bahwa kelebihan metode sumuran yaitu lebih mudah mengukur luas zona hambat yang terbentuk karena isolat beraktivitas tidak hanya dipermukaan atas nutrient agar tetapi juga sampai kebawah.

Pada penelitian ini digunakan media NA karena media NA merupakan media yang umum 
digunakan dalam prosedur bakteriologi seperti uji biasa dari air, sewage, produk pangan, untuk membawa stok kultur, untuk pertumbuhan sampel pada uji bakteri dan untuk mengisolasi organisme dalam kultur murni (Radji, 2010). Selain itu media NA juga mengandung glukosa dan peptone yang merupakan sumber karbohidrat dan protein bagi pertumbuhan kapang dan bakteri. Konsentrasi yang digunakan dalam penelitian ini yaitu konsentrasi 5\%, $10 \%, 20 \%$ dan $40 \%$.

Hasil uji aktivitas antibakteri ekstrak air kulit bawang merah dengan konsentrasi 5\%, 10\%, 20\% dan $40 \%$ serta klindamisin $1 \%$ sebagai kontrol positif dan DMSO $1 \%$ v/v sebagai kontrol negatif terhadap Propionibacterium acnes dapat dilihat pada Tabel 2. Berdasarkan hasil penelitian pada Tabel 2 menunjukkan bahwa kontrol negatif pada perlakuan menggunakan dimetil sulfoksida tidak terlihat zona hambat. Hal ini terjadi karena dimetil sulfoksida merupakan senyawa organosulfur dan hanya digunakan untuk mengencerkan ekstrak. Cairan ini bersifat tidak toksik sehingga tidak memberikan daya hambat pertumbuhan bakteri dan tidak mengganggu hasil pengamatan aktivitas antibakteri (Pratiwi, 2008).

Tabel 2. Hasil pengukuran zona hambat bakteri Propionibacterium acnes

\begin{tabular}{|c|c|c|}
\hline & $\begin{array}{l}\text { Rata-rata diameter } \\
\text { zona hambat }(\mathrm{mm})\end{array}$ & $\begin{array}{c}\text { Kriteria daya hambat } \\
\text { (David dan stout) }\end{array}$ \\
\hline Kontrol negatif & 0 & Tidak ada \\
\hline P1 & $12,8 \pm 0,305$ & Kuat \\
\hline $\mathrm{P} 2$ & $13,0 \pm 0,4$ & Kuat \\
\hline P3 & $14,33 \pm 0,29$ & Kuat \\
\hline P4 & $15,50 \pm 0,5$ & Kuat \\
\hline Kontrol positif & $40,50 \pm 0$ & Sangat kuat \\
\hline \multicolumn{3}{|l|}{ Keterangan: } \\
\hline Kontrol positif & : Klindamisin $1 \%$ & \\
\hline Kontrol negatif & : DMSO 1\% (v/v) & \\
\hline $\mathrm{P} 1$ & : Konsentrasi 5\% & \\
\hline $\mathrm{P} 2$ & : Konsentrasi $10 \%$ & \\
\hline P3 & : Konsentrasi $20 \%$ & \\
\hline P4 & : Konsentrasi $40 \%$ & \\
\hline
\end{tabular}

Hasil dari perlakuan kontrol positif yaitu klindamisin terbentuk zona hambat yang paling besar dengan ratarata zona hambat sebesar $40,50 \mathrm{~mm}$, hal ini dikarenakan klindamisin merupakan senyawa murni yang memiliki spektrum luas yang efektif dapat menghambat bakteri gram positif dan gram negatif. Mekanisme kerjanya terjadi ikatan secara reversibel dengan subunit ribosomal 50S, mencegah terjadinya ikatan peptida sehingga akan menghambat sistesis protein bakteri; efek bakteriostatik atau bakterisidal tergantung dari konsentrasi obat, 
infeksi dan jenis organisme (Ganiswara dkk, 1995).

Berdasarkan hasil pada semua perlakuan ekstrak air kulit bawang merah didapatkan hasil zona hambat yang berbeda-beda. Perbedaan konsentrasi mempengaruhi besar kecilnya zona hambat. Penghambatan pertumbuhan bakteri disebabkan oleh senyawa kimia yang terkandung pada ekstrak air kulit bawang merah, pada penelitian ini semakin tinggi konsentrasi yang digunakan, semakin besar pula zona hambat yang dihasilkan. Hal ini sesuai dengan teori, semakin tinggi konsentrasi suatu zat antibakteri, maka semakin tinggi daya antibakterinya (Pelczar dan Chan, 2008).

Hasil skrining fitokimia kulit bawang merah mengandung zat aktif berupa senyawa flavonoid, tanin dan saponin. Mekanisme kerja flavonoid sebagai antibakteri adalah mendenaturasi protein sel bakteri dan dapat merusak membran sitoplasma (Pelczar dan Chan, 1988). Mekanisme kerja tanin sebagai antibakteri adalah menghambat enzim reverse transkiptase dan DNA topoisomerase sehingga sel bakteri tidak dapat terbentuk (Robinson, 1995). Mekanisme kerja saponin sebagai antibakteri adalah menurunkan tegangan permukaan sehingga mengakibatkan naiknya permeabilitas atau kebocoran sel dan mengakibatkan senyawa intraseluler akan keluar (Robinson, 1995).

Data yang diperoleh dianalisis menggunakan SPSS versi 20. Pada uji sampel Kolmogorov-Smirnov test didapat hasil 0,036 menunjukkan bahwa $p$-value kurang dari 0,05 atau signifikasi kurang dari 0,05. Hal ini menunjukkan bahwa data yang diperoleh peneliti berdistribusi tidak normal sehingga tidak dapat dilakukan dengan analisis One Way Anova dan dilakukan menggunakan analisis uji Kruskal-Wallis test. Berdasarkan uji Kruskal-Wallis test didapat hasil 0,053 menunjukkan bahwa uji tersebut memiliki signifikasi > 0,05 dengan keputusan yang berarti tidak terdapat perbedaan bermakna dari hasil perlakuan pada daya hambat antibakteri masing-masing konsentrasi ekstrak air kulit bawang merah. Pada uji Kruskal-Wallis test antara perlakuan dengan kontrol negatif didapat hasil 0,011 menunjukkan bahwa uji tersebut memiliki signifikasi $<0,05$ dengan keputusan yang berarti terdapat perbedaan bermakna dari daya hambat antibakteri hasil perlakuan terhadap kontrol negatif. Sedangkan uji Kruskal-Wallis test antara perlakuan dengan kontrol positif didapat hasil 0,012 menunjukkan bahwa uji tersebut memiliki signifikasi $<0,05$ dengan keputusan yang berarti terdapat perbedaan bermakna dari daya hambat antibakteri hasil perlakuan terhadap kontrol positif. Hal ini menunjukkan bahwa ekstrak air kulit bawang mempunyai kemampuan menghambat bakteri Propionibacterium acnes namun kekuatannya tidak sebesar control positif yaitu klindamisin $1 \%$.

\section{SIMPULAN}

Berdasarkan penelitian yang telah dilakukan dapat disimpulkan 
bahwa ekstrak air kulit bawang merah pada konsentrasi 5\%, 10\%, $20 \%$ dan $40 \%$ dapat menghambat bakteri Propionibacterium acnes dengan diameter zona hambat berturut- turut sebesar $12,8 \mathrm{~mm}, 13$ $\mathrm{mm}, 14,33 \mathrm{~mm}$ dan $15,50 \mathrm{~mm}$ dengan kategori kuat.

\section{UCAPAN TERIMAKASIH}

Pada kesempatan ini, peneliti ingin mengucapkan terima kasih kepada berbagai pihak yang telah membantu terwujudnya penelitian ini :

1. Ketua Sekolah Tinggi Ilmu Kesehatan Samarinda yang telah mengizinkan penggunaan fasilitas laboratorium Farmakognosi dan Mikrobiologi, Stikes Samarinda

2. Ketua Lembaga Penelitian dan Pengabdian Stikes Samarinda yang telah memberikan dukungan dana publikasi artikel ilmiah.

\section{DAFTAR PUSTAKA}

Arif, M. 2015. Uji Aktivitas Antibakteri Ekstrak Terpurifikasi Kulit Bawang Merah (Allium cepa L.) Terhadap Bakteri Staphylococcus aureus. Karya Tulis Ilmiah. Samarinda: D-III Farmasi Akademi Farmasi Samarinda. Hal: 45

David, W.W dan T.R. Stout. 1971. Disc Plate Methods of Microbiological Antibiotic Assay. Microbiology: American Society of Microbiology. Hal: 664

Ganiswara, G., Suliatia, dkk,. 1995. Farmakologi Dan Terapi Edisi
IV. Jakarta: Fakultas Kedokteran UI

Harborne, J. B. 1987. Metode Fitokimia. Diterjemahkan oleh Kosasih Padmawinata dan Iwang Soediro, Terbitan Kedua. Penerbit ITB, Bandung.

Jawetz, E., Melnick, J. L., Adelberg, E.A.M. 2001. Mikrobiologi Kedokteran. Edisi 23, diterjemahkan oleh bagian Mikrobiologi Fakultas Kedokteran Universitas Airlangga, 205-209. Jakarta: Penerbit Salemba Medika. Hal: 225-231

Kokate,

C.K. 2001. Pharmacognosy.16tn Edition. 181- 183: Mumbai India

Manullang, L. 2010. Karakterisasi Simplisia, Skrining Fitokimia dan Uji Toksisitas Ekstrak Kulit Umbi Bawang Merah (Allii cepae var. ascolinicum) dengan Metode Uji Brine Shrimp (BST). Skripsi. Medan: Universitas Sumatera Utara

Naidu, S.P.V., Kinthada, Prakash M.M.S., Muralidhar, P.K. 2012. Characterization and Biological Activities of Quercetin Thiosemicarbazone Derivates: Potential Anti Cancer Drugs. Int J Pharm Biomed Sci3(2) 24-27 ISSN No: 0976-5263.

Pelczar, M dan Chan, E. C. S. 1988. Dasar-dasar Mikrobiologi. 
Jakarta: Penerbit UI-Press. Hal: 449-455

Pratiwi, S.T. 2008. Mikrobiologi Farmasi. Jakarta: Erlangga.

Radji, M. 2010. Buku Ajar Mikrobiologi Panduan Mahasiswa Farmasi dan Kedokteran. Jakarta: EGC. Hal: 103-111

Robinson, T., 1995. Kandungan Organik Tumbuhan Tinggi, diterjemahkan oleh Kosasih, P., Edisi Keenam. Bandung: ITB. Hal: 72,157,198

Soebagio, B., Rusdiana, T., Khairudin. 2007. Pembuatan Gel Dengan Aqupec HV-505 dari
Ekstrak Umbi Bawang Merah (Allium cepa L.) Sebagai Antioksidan. Jurnal Seminar Penelitian. Padjajaran: Fakultas Farmasi- Universitas Padjajaran

Sugita, T., Miyamoto, M., Tsuboi, R., Takatori, K., Ikeda, R., And Nishikawa, A. 2010. In Vitro Activities of Azole Antifungal Agents agains Propionibacterium acnes Isolated from Patients with Acne Vulgaris. Biol Pharm Bull 33(1): 125-127. 